\title{
Curative Effect of Bone Marrow Cells Transplantation and/or Low Dose Gamma Irradiation on Liver Injuries Induced by Carbon Tetrachloride
}

\author{
* Mohamed E.M. Zowail, ** Hanaa F. M. Waer, ** Noaman A. Eltahawy, * Eman H. S. \\ Khater and *** Amr M. Abd El-hady. \\ * Faculty of Science, Benha University. ** National Center for Radiation Research and \\ Technology, Atomic Energy Authority, Cairo, *** Faculty of Applied Medical Sciences, \\ Misr University for Science and Technology.
}

\begin{abstract}
Liver is the most common target for toxic injury. Toxic agents include chemicals such as carbon tetrachloride $\left(\mathrm{CCl}_{4}\right)$ and trichloroethylene. This study aimed to evaluate the effect of bone marrow cells (BMC) transplantation and/or fractionated low doses (0.5 Gy) gamma radiation on established liver fibrosis induced by $\mathrm{CCl}_{4}$. BMCs of male albino rats were transplanted into 4 -weeks carbon tetrachloride $\left(\mathrm{CCl}_{4}\right)$-treated and/or fractionated low doses $(0.5 \mathrm{~Gy})$ gamma irradiated rats through the tail vein, and the rats were treated for 4 more weeks with $\mathrm{CCl}_{4}$ (total 8 weeks). Histological and ultrastructural investigations revealed that both bone marrow cells transplantation and low dose $(0.5$ Gy) gamma radiation exposure with continuous $\mathrm{CCl}_{4}$ injection had reduced liver fibrosis as compared with rats treated with $\mathrm{CCl}_{4}$ alone.
\end{abstract}

\section{Introduction}

Liver is an important organ which is actively involved in many metabolic functions and it is the frequent target for a number of toxicants. Hepatic damage is associated with distortion of these metabolic functions. Carbon tetrachloride is a highly toxic chemical agent which causes hepatic injury. Prolonged administration of $\mathrm{CCl}_{4}$ causes fibrosis, cirrhosis and hepatic carcinoma (Wernke and Schell, 2004). Evidences indicated that oxidative stress might be a pivotal originating factor in the pathogenesis of $\mathrm{CCl}_{4}$-induced liver diseases (Kamalakkannan et al., 2005). Hepatic fibrosis caused by $\mathrm{CCl}_{4}$ has been extensively used in experimental models in rats because hepatic responses in rats to chronic $\mathrm{CCl}_{4}$ stimulation are shown to be superficially similar to human cirrhosis (Smyth et al., 2007).

Carbon tetrachloride induces hepatotoxicity by metabolic activation; where it is biotransformed by cytochrome $\mathrm{P}_{450}$ system in the endoplasmic reticulum to produce trichloromethyl free radical $\left({ }^{*} \mathrm{CCl}_{3}\right)$. Trichloromethyl free radical when combined with cellular lipids and proteins in the presence of oxygen form trichloromethylperoxyl radical, which may attack lipids on the membrane of endoplasmic reticulum faster than trichloromethyl free radical. Thus, trichloromethylperoxyl free radical elicits lipid peroxidation, the destruction of $\mathrm{Ca}^{2+}$ homeostasis and finally results in cell death (Rajeswary et al., 2011).

Low doses of gamma rays have been demonstrated to induce defense such as detoxification of reactive oxygen species (Feinendegen et al., 2004), induce highfidelity repair of DNA damage (Rothkamm and Löbrich, 2003), protect from chromosomal damage caused by subsequent high radiation dose and protect from spontaneous mutations occurrence (Hooker $\boldsymbol{e t}$ al., 2004) and activate the immune response (Liu, 2003, 2004). It also stimulates various biological functions: anti-oxidative capacity, DNA repair capability and apoptosis (Sakai, 2000), enzymatic repair, immunological and apoptotic removal of DNA damage (Pollycove and Feinendegen, 2000). Chronic low doses of gamma radiation are known to stimulate prevention and repair of DNA damage and the immune system, which decreases the gene mutation rate, leading to the beneficial effects of decreased mortality in general and decreased cancer mortality specifically (Cuttler, 2001). Therapeutic stimulation of these defenses by low dose body irradiation prevents and removes cancer metastases in mice, rats and humans.

Liver cirrhosis represents the final common pathological outcome for the majority of 
chronic liver diseases, it leads to hepatocellular dysfunction and increases intrahepatic resistance to blood flow, resulting in hepatic insufficiency and portal hypertension (Gines et al., 2004) and often requires liver transplantation. Recently, stem cell-based cytotherapy has shown promising benefit on animal models and some clinical patients. Bone marrow is the most fertile tissue harboring various stem cells. According to Sakaida et al. (2004) bone marrow cells are also responsible for the resolution of liver fibrosis induced by $\mathrm{CCl}_{4}$ treatment. Terai $\boldsymbol{e t}$ al. (2006) reported that there was a significant improvement in serum albumin levels and total protein in liver cirrhosis patients who underwent autologous bone marrow cell infusion. Cao et al. (2007) stated that bone marrow cells infused into $\mathrm{CCl}_{4}$ administrated rats showed improvement of liver fibrosis. The study of Dai et al. (2009) showed that transplantation of autologus bone marrowderived mesenchymal stem cells holds great potential for treating hepatic cirrhosis. More recently, Sun et al. (2010) demonstrated a positive impact of intra-portal bone marrow cells infusion in enhancing regeneration and reducing fibrosis of the regenerating fibrotic liver in rats.

The aim of the present study is to evaluate the role of bone marrow cells transplantation and fractionated low doses $(0.5$ Gy) gamma irradiation against carbon tetrachloride induced liver fibrosis.

\section{Material and methods}

Forty male Swiss Albino rats (Rattus norvigicus) (250-300 g.) were used. The rats were given laboratory fed, water ad libitum and kept under suitable conditions.

\section{Carbon tetrachloride administration:}

Rats were injected intraperitoneally with $1 \mathrm{ml} / \mathrm{kg}$ body weight of a mixture of $\mathrm{CCl}_{4}$ (ElNasr Chemical Company, Cairo, Egypt) dissolved in olive oil (1:1) two successive times at three days intervals per week.

\section{Radiation Facility}

Whole body gamma irradiation was performed using the facilities provided by the National Center for Radiation Research and Technology (NCRRT, Cairo. Cesium - 137 irradiation unit (Gamma Cell -40) at a dose rate of $0.46 \mathrm{~Gy} / \mathrm{min}$. During the experimentation period animals were whole body exposed to $0.5 \mathrm{~Gy}$ delivered as a single shot dose twice a week.

Animals were divided into seven groups (10 rats per group); Experimental animals have been sorted into the following groups:

1. Normal Control group: rats were none treated and none irradiated.

2. Carbon tetrachloride administrated group: $1 \mathrm{ml} / \mathrm{kg}$ body weight of $\mathrm{CCl}_{4}$ administrated twice a week for eight weeks.

3. Carbon tetrachloride and bone marrow group: Rats of this group injected with $\mathrm{CCl}_{4}$ for four weeks, then injected with $1 \mathrm{ml}$ of bone marrow cells per $\mathrm{Kg}$ of rat body weight (one time at the end of the fourth week) and injected again with the same dose of $\mathrm{CCl}_{4}$ for another four weeks.

4. Irradiated group: Rats irradiated with $0.5 \mathrm{~Gy}$ of gamma radiation twice a week for eight weeks.

5- Irradiation and bone marrow group: Rats of this group irradiated with 0.5 Gy of gamma radiation for four weeks, then injected with $1 \mathrm{ml}$ of bone marrow cells per $\mathrm{Kg}$ of rat body weight (one time by the end of the fourth week) and irradiated again for another four weeks .

6. Gamma irradiated and carbon tetrachloride administrated group: Rats of this group received the same dose $\mathrm{CCl}_{4}$ and exposed to $0.5 \mathrm{~Gy}$ of whole body gamma radiation for eight weeks.

7. Gamma irradiated, carbon tetrachloride administrated and bone marrow group: Rats of this group irradiated and injected with $\mathrm{CCl}_{4}$ for four weeks, then injected with bone marrow cells per $\mathrm{Kg}$ of rat body weight (one time at the end of the fourth week) and continue the process of irradiation and $\mathrm{CCl}_{4}$ injection for another four weeks.

\section{Rat bone marrow preparation:}

The bone marrow donors were young, 6 weeks old, male Swiss Albino rats, donors and recipients were chosen from the same inherited strain (brother to brother), which were killed by scarification. The ends of the femurs were cut of with a bone cutter, by applying gentle air pressure the marrow was forced out into small sterile Pyrex test tube; it was thus possible to obtain $40-50 \mathrm{mg}$ bone 
marrow (wet weight) from each femur. The weighted bone marrow was then suspended in an appropriate volume of chilled $\mathrm{M} / 15$ phosphate buffer $(\mathrm{pH}=7.2)$. One $\mathrm{ml}$ of bone marrow suspension in phosphate buffer was injected via the tail vein of the experimental rats by using a 26 gauge needle (Kwon $\boldsymbol{e t}$ al., 2008).

Rats were killed by scarification and livers of the animals were removed. Tissues were fixed in Bouin's fluid for routine histological study. After trimming the tissues were processed through graded alcohol for dehydration, cleared in cider wood oil and embedded in paraffin. Paraffin sections were made at $5 \mu$ and stained with haematoxylin \& eosin. Sections were examined under a light microscope. Samples for electron microscopy were fixed by immersion in $3 \%(\mathrm{v} / \mathrm{v})$ glutaraldehyde in $0.1 \mathrm{~mol}$ cacodylate buffer $1: 1(\mathrm{pH}=7.4)$, post fixed in $1 \%(\mathrm{v} / \mathrm{v})$ osmium tetroxide, dehydrated in a graded series of ethanol and embedded in epoxy resin. Semi thin sections were performed for purpose of orientation. Ultra-thin sections were examined under the electron microscope after staining with uranyl acetate and lead citrate (Skepper and Powell, 2006). Sections were examined and photographed with SEO transmission E.M at the Veterinary Hospital, Electron Microscopy Unit, Nasr City, Cairo,

\section{Results}

\section{1- Histological observations:}

Group (1): Control normal group

Light microscopic examination of liver sections of control normal rats stained with $\mathrm{H}$ $\&$ E showed that it consists of well defined hexagonal or pentagonal classic hepatic lobules each is traversed contrarily by a central vein; polygonal medium sized hepatocytes are arranged in plates radiating, branching and anastomosing from the central vein. Each hepatocyte contains a single central rounded vesicular nucleus; some of the hepatocytes are binucleated. The cytoplasm contains basophilic granules. The sinusoids are composed of endothelial cells and contain phagocytic cells known as Von kupffer cells (Fig. 1a,b).
Group (2): Rats injected with $\mathrm{CCl}_{4}$ (twice a week for 8 weeks)

Light microscopic examination of liver sections of this group showed that hepatocytes lost their normal architecture which appeared in haphazard fashion. Hepatocytes swelling, cytoplasmic degeneration and granulation (primary stage of carcinoma) and variation in liver cell sizes were also seen. Fatty changes persistent with scattered inflammatory foci were also noted (Fig. 2). Some hepatocytes were greatly disintegrated with the appearance of areas of necrosis (Fig. 3).

Group (3): Rats injected with $\mathrm{CCl}_{4}$ and bone marrow

Bone marrow cells injection to the rats of this group revealed hepatocytes regeneration as most of the hepatocytes nuclei restored their normal appearance while others showed that the process of degeneration proceeded to necrotic areas (Fig. 4).

Group (4): Rats irradiated with 0.5 Gy of gamma radiation (twice a week for 8 weeks) Light microscopic examination of liver sections of this group showed some hepatocytes acquired normal appearance with the appearance of some areas of necrosis (Fig. $5)$.

Group (5): Rats irradiated and injected with bone marrow cells

Light microscopic examination of liver sections of this group showed an improvement where some hepatocytes nuclei appeared in mitotic division ( Fig. 6).

Group (6): Rats injected with $\mathrm{CCl}_{4}$ and irradiated with $0.5 \mathrm{~Gy}$ of gamma radiation (twice a week for 8 weeks)

Light microscopic examination of liver sections of this group showed that most hepatocytes appeared healthy with normal blood sinusoids. Some of the hepatocytes nuclei were in mitotic stage with condensed granulated cytoplasmic (Fig. 7).

Group (7): Rats injected with $\mathrm{CCl}_{4}$, irradiated with 0.5 Gy of gamma radiation (twice a week for 8 weeks) and injected with bone marrow

Bone marrow cells transplantation to the rats of this group showed nearly normal appearance of the hepatocytes, blood sinusoids and activated nuclei (Fig. 8). 

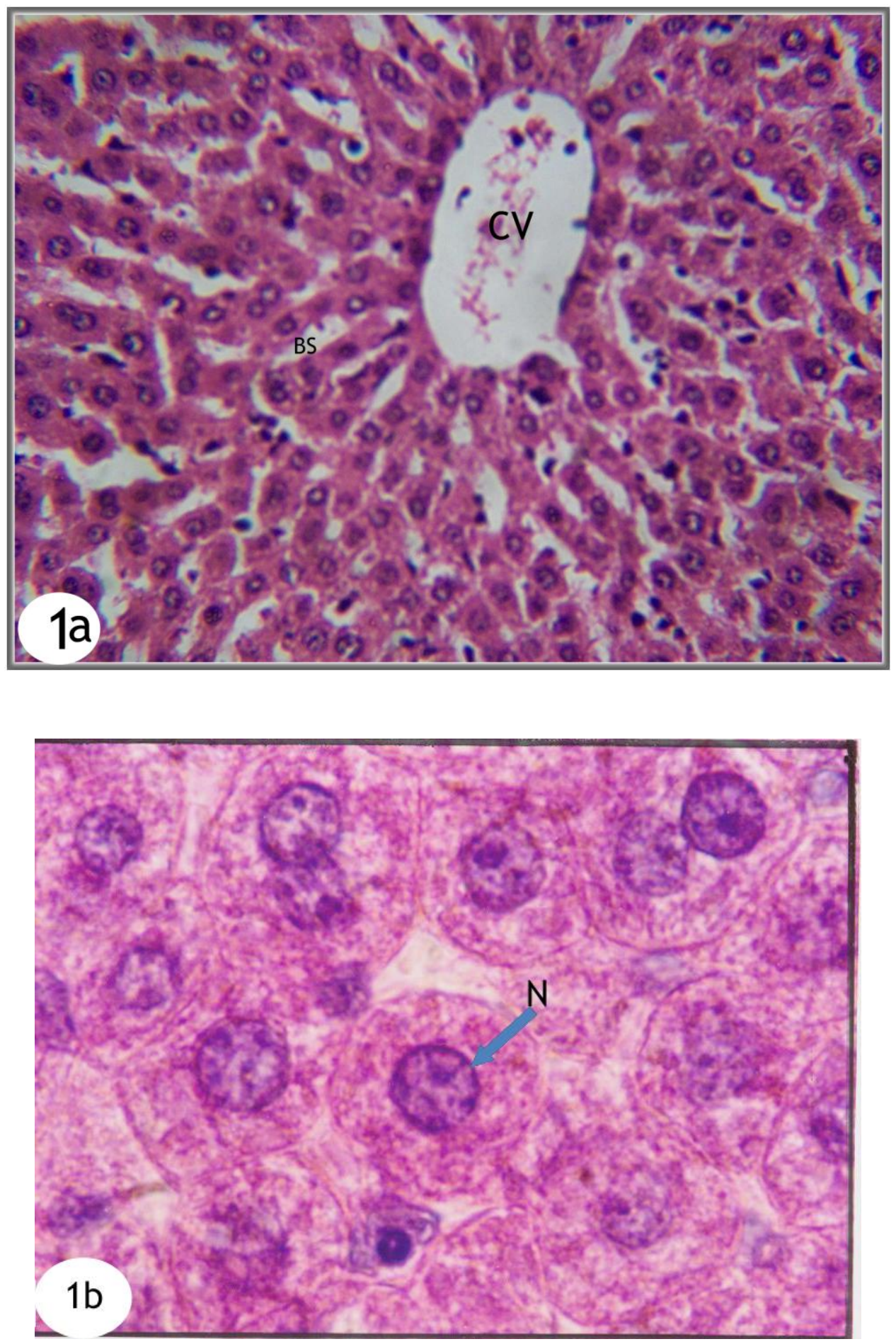

Fig. (1, a,b): A light micrograph of a part of liver section of control normal rat showing the normal lobular pattern of the liver with a centrilobular vein (CV) and radiating irregular anastomosing plates of hepatocytes with their nuclei $(\rightarrow$ ) and intervening blood sinusoids (BS) (H \& E X 400). 


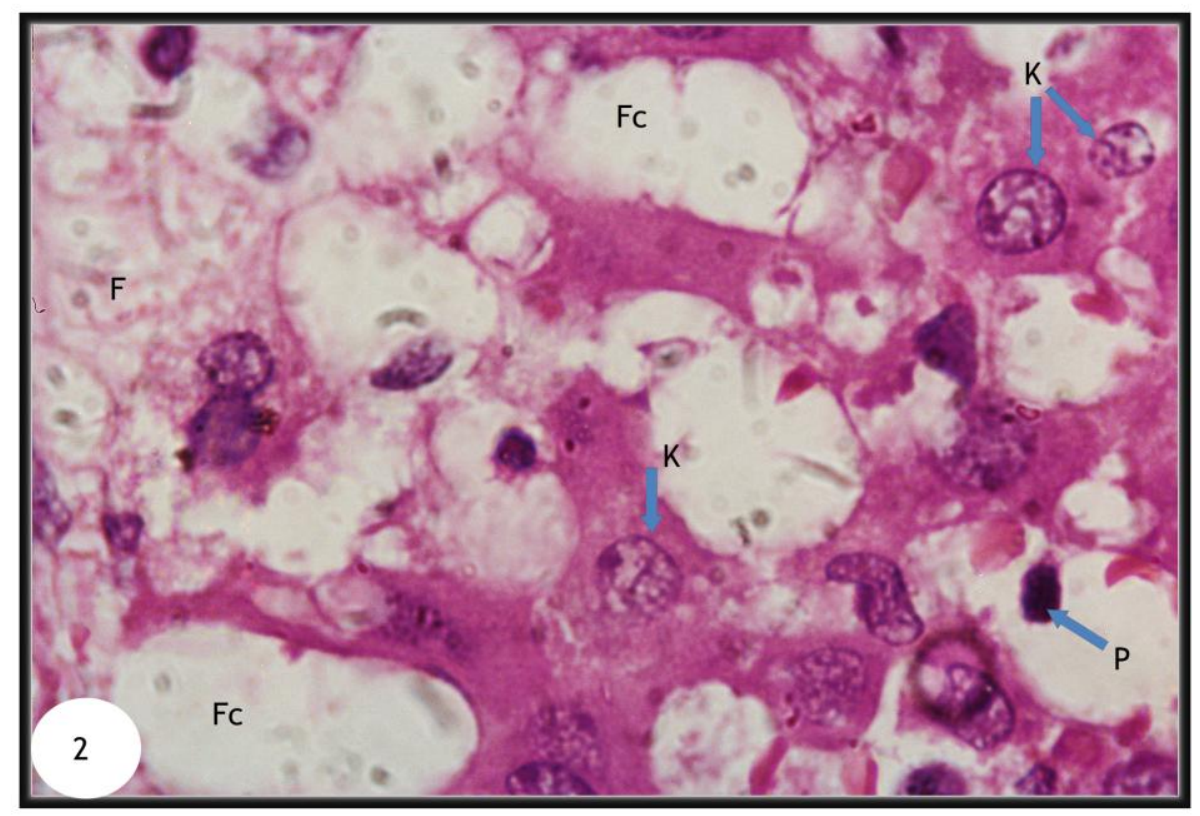

Fig. (2): A light micrograph of a part of liver section of rat injected with carbon tetrachloride $(1 \mathrm{ml} / \mathrm{kg}$, twice a week) for 8 weeks showing, fatty changes $(\mathrm{Fc})$ persistent with scattered inflammatory foci $(\mathrm{F})$, pyknotic nuclei (P) and karyolytic ones(K) (H \& E X 1000).

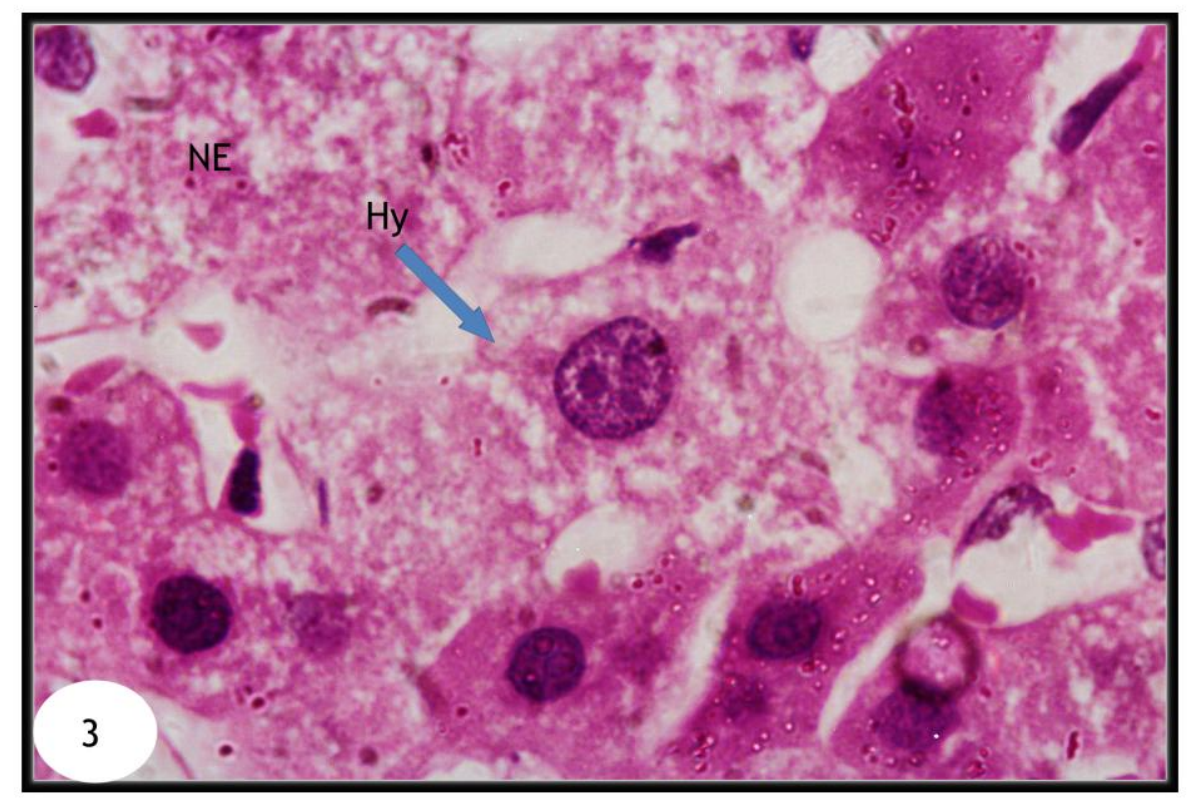

Fig. (3): A light micrograph of a part of liver section of rat injected with $\mathrm{CCl}_{4}(1 \mathrm{ml} / \mathrm{kg}$, twice a week) for 8 weeks showing necrosis (NE), hepatocytes hypertrophy $(\rightarrow)$, cytoplasmic degeneration and some cells were greatly disintegrated $(H \quad \& \quad E \quad$ X 1000). 



\section{Curative Effect of....}

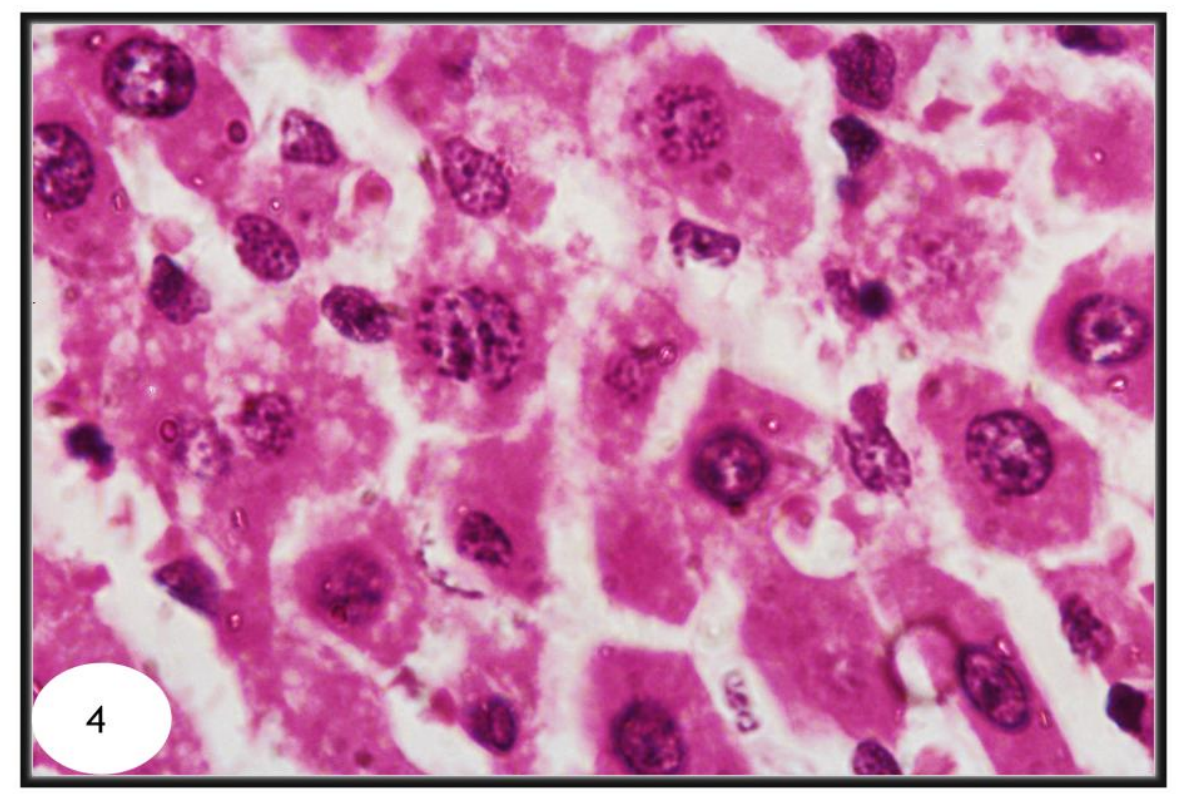

Fig. (4): A light micrograph of a part of liver section of rat injected with $\mathrm{CCl}_{4}(1 \mathrm{ml} / \mathrm{kg}$, twice a week) for 8 weeks and treated with bone marrow cells showing hepatocytes regeneration as most of the nuclei restored their normal appearance, while others showed that the process of degeneration proceeded to necrotic areas with dilated sinusoidal spaces (H \& E X 1000).

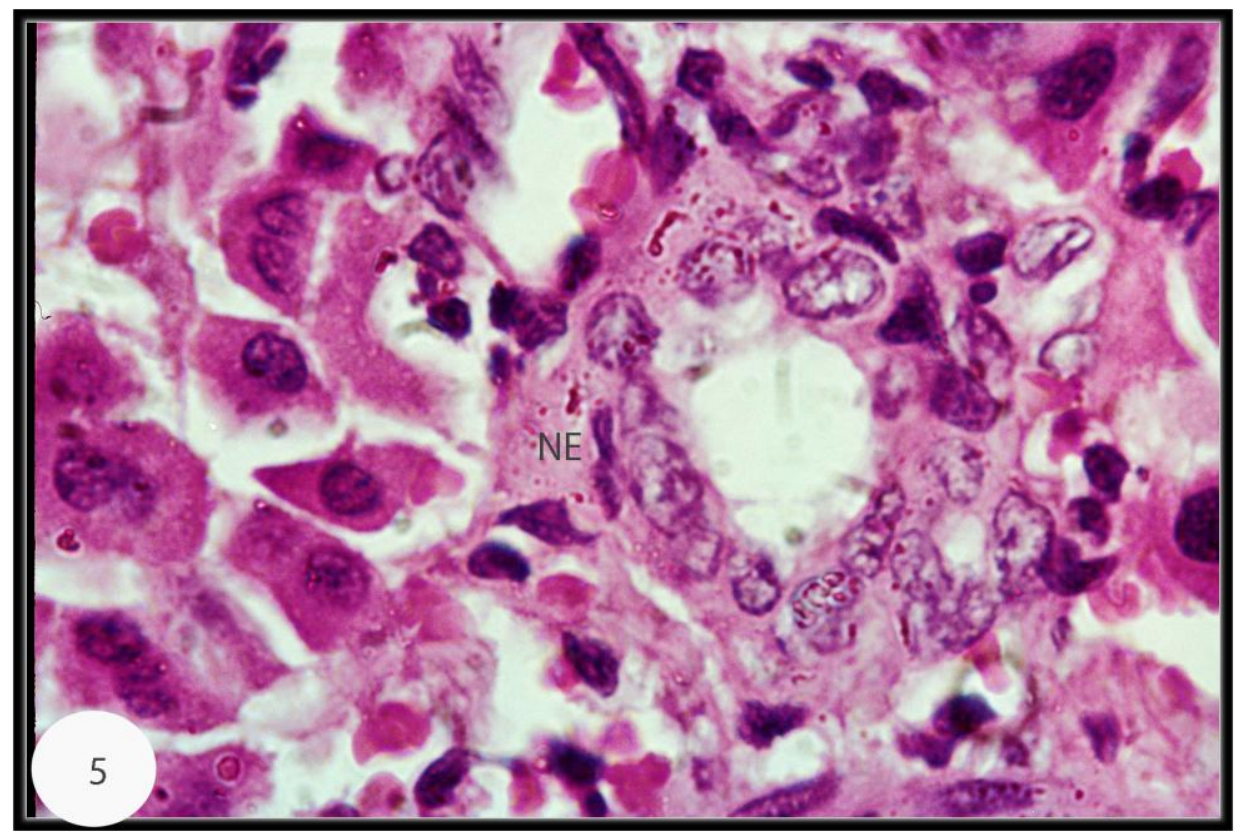

Fig. (5): A light micrograph of a part of liver section of rat of low dose 0.5 Gy gamma irradiation for 8 weeks showing areas of necrosis $(\mathrm{NE})$, while some hepatocytes acquired normal appearance $(\mathrm{H} \& \mathrm{E}$ X 1000). 


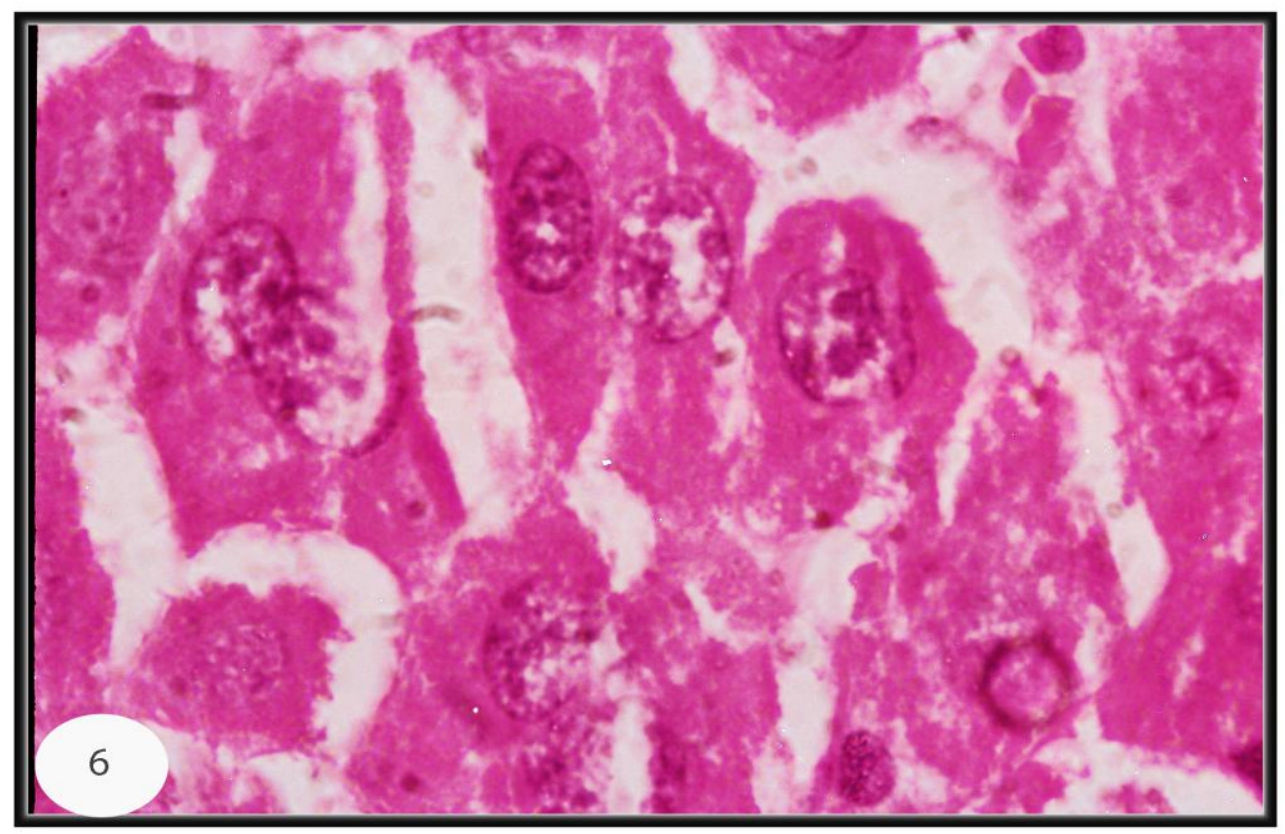

Fig. (6): A light micrograph of a part of liver section of rat of low dose 0.5 Gy gamma irradiation for 8 weeks and treated with bone marrow cells showing mitotic division with some fatty changes $(\mathrm{H} \& \mathrm{E}$ X 1000).

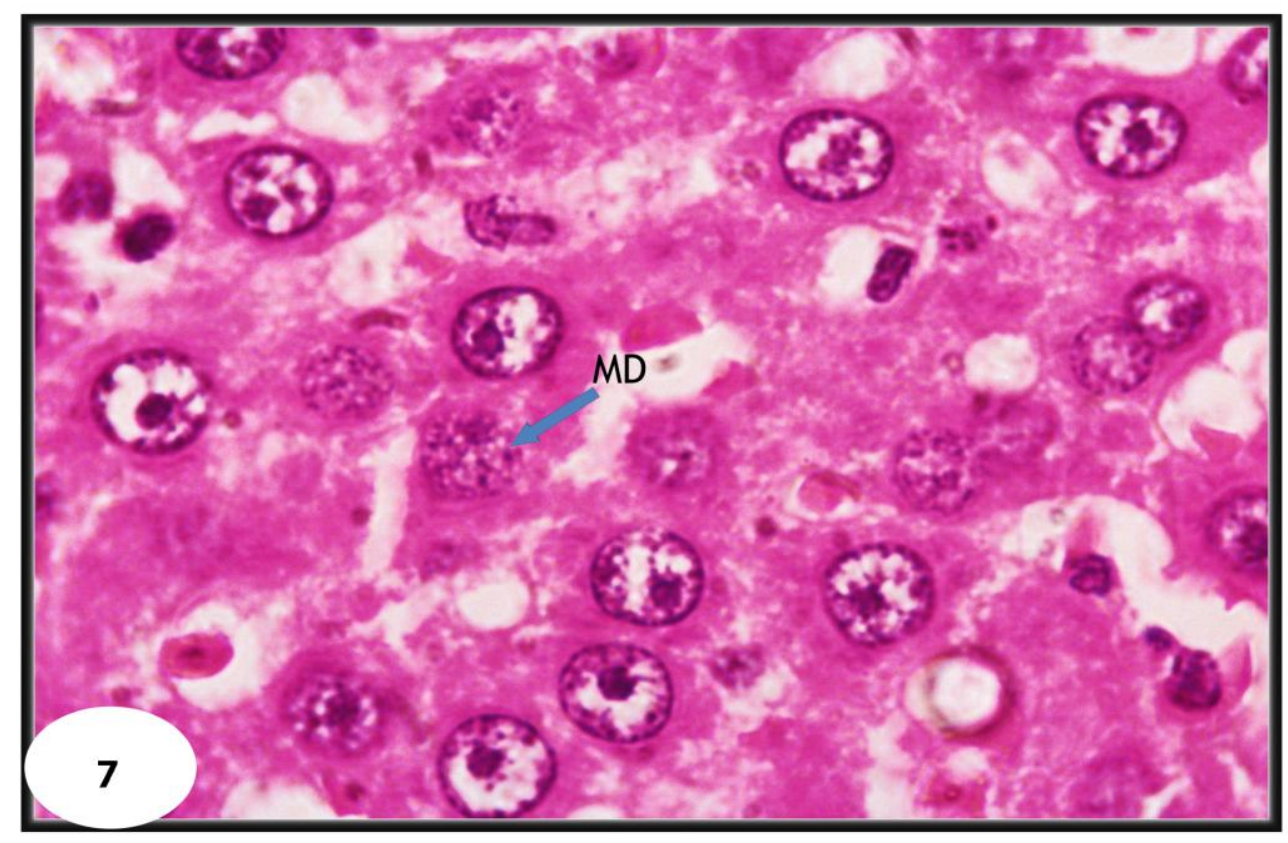

Fig. (7): A light micrograph of a part of liver section of rat irradiated with $0.5 \mathrm{~Gy}$ gamma radiations and injected with $\mathrm{CCl}_{4}$ for 8 weeks showing well defined regenerating hepatocytes, some of the nuclei were in mitotic stage (MD) with condensed granulated cytoplasmic appearance (H \& E X 1000). 


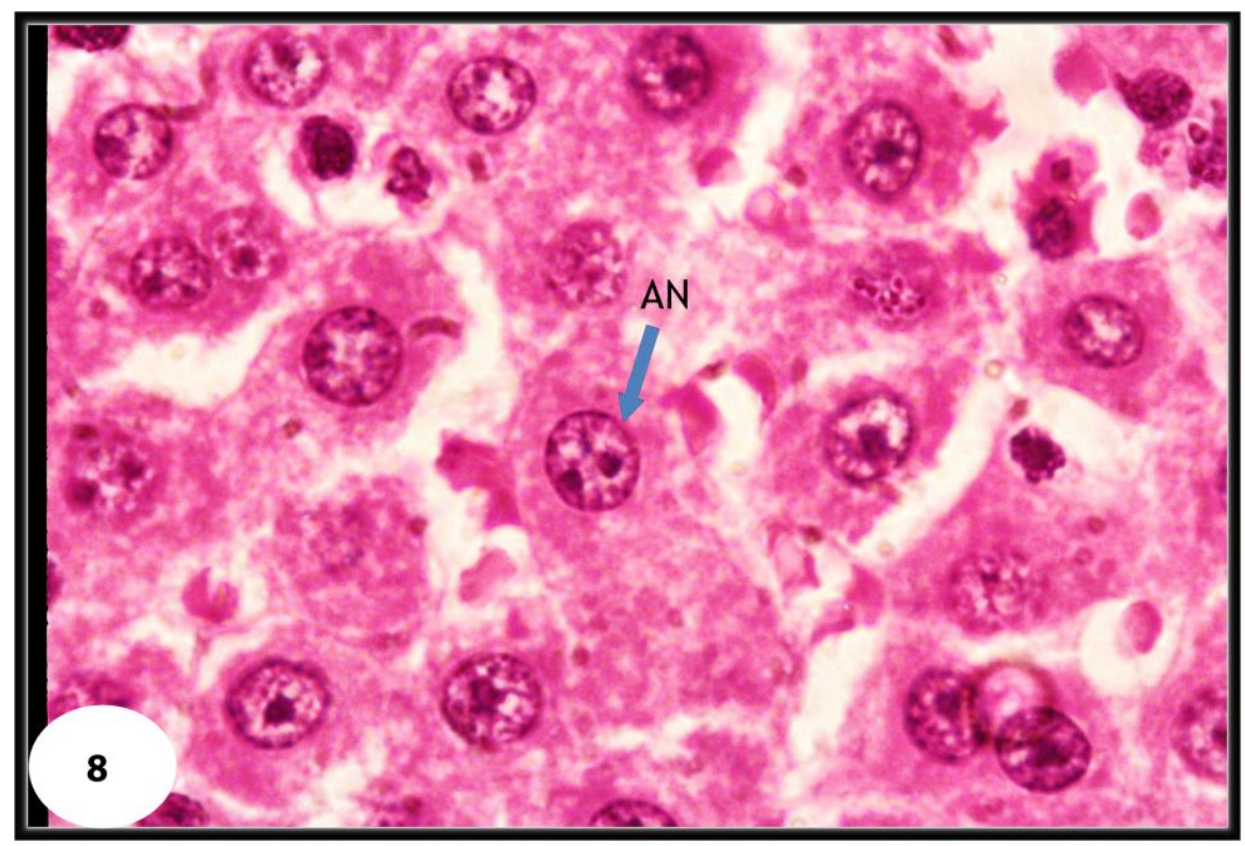

Fig. (8): A light micrograph of a part of liver section of rat irradiated with 0.5 Gy gamma radiations, injected with $\mathrm{CCl}_{4}$ for 8 weeks and treated with bone marrow cells showing well organized cells with activated nuclei (AN) and binucleated cells (H \& E X 1000).

\section{2- Ultra structural observations:}

\section{Group (1): Control normal group}

Ultrastructural examination of normal control liver cells showed hepatic cells with homogeneous cytoplasm contains healthy and well defined rounded mitochondria, the rough endoplasmic reticulum is well organized with partially attached ribosomes; numerous free ribosomes are distributed throughout it and smooth endoplasmic reticulum. Glycogen rosette forms are also seen in the ground cytoplasm. The nucleus appeared spherical in shape and surrounded by its nuclear envelope as a double membrane. Two types of chromatin materials are found within each nucleus, heterochromatin, appeared attached to the inner side of the nuclear envelope and euchromatin, appeared distributed throughout the nucleus with eccentric nucleolus (Fig. 9).

\section{Group (2): Rats injected with $\mathrm{CCl}_{4}$ (twice a week for 8 weeks)}

Ultrastructural examination of a liver cell of this group showed that the cells were irregular in structure. The cytoplasm is degenerated, mitochondria appeared to be malformed, fragmented rough endoplasmic reticulum and increased amount of lipid droplets, excess collagen fibers deposition, disintegrated chromatin inside the nucleus and areas of necrosis were also noted (Figs. $10 \& 11$ ).

Group (3): Rats injected with $\mathbf{C C l}_{4}$ and bone marrow

Bone marrow cells injection to the rats of this group showed marked amelioration where hepatocytes seemed to be normal, the cytoplasm appeared homogenous with polymorphic electron dense mitochondria with normal patches of rough endoplasmic reticulum, increased amounts of glycogen particles and decreased amounts of lipid droplets and collagen fibers as compared to group (2). The nucleus looked to be healthy with double membrane and distinct pores with normal distribution of euchromatin and heterochromatin and homogenous nuclear sap (Figs. 12 \& 13).

Group (4): Rats irradiated with 0.5 Gy of gamma radiation (twice a week for 8 weeks) Ultrastructural examination of the liver cells of this group revealed that the hepatocytes cytoplasm appeared granulated, mitochondria appeared almost normal in shape and size, but some of them were electron dense, well organized rough and smooth endoplasmic 
reticulum were observed with normal appearance of glycogen. Nucleus appeared to be healthy with prominent nucleolus and homogenous euchromatin distribution with marginal heterochromatin (Fig. 14).

Group (5): Rats irradiated with 0.5 Gy of gamma radiation and bone marrow cells

Ultrastructural examination of the liver cells of this group showed that the hepatocytes cytoplasm appeared more or less normal, some hepatocytes showed healthy regenerated electron dense mitochondria with transverse cristae bounded by double membrane, rough and smooth endoplasmic reticulum appeared healthier and well organized with ribosomal attachment, normal collagen fibers was evident. Nucleus containing well distributed euchromatin with marked heterochromatin attached to the inner nuclear envelope was also depicted (Fig. 15).

Group (6): Rats injected with $\mathrm{CCl}_{4}$ and irradiated with $0.5 \mathrm{~Gy}$ of gamma radiation (twice a week for 8 weeks)

Ultrastructural examination of a liver cell of this group revealed an obvious improvement of the hepatocytes, where cytoplasm appeared homogenous with more or less hypertrophied mitochondria with ruptured cristae, ruptured endoplasmic reticulum still evident and glycogen rosettes also appeared scattered through out the cytoplasm. Nucleus appeared rounded with distinct outer and inner membranes; peripheral heterochromatin was clearly attached to the inner nuclear envelope and dilated nuclear envelope (Figs. 16\& 17).

Group (7): Rats injected with $\mathbf{C C l}_{4}$ and irradiated with $0.5 \mathrm{~Gy}$ of gamma radiation (twice a week for 8 weeks) and injected with bone marrow

Bone marrow cells transplantation to the rats of this group showed nearly no pathological changes where the hepatocytes appeared with well defined cytoplasm containing mitochondria with different shapes, rough endoplasmic reticulum with partially attached ribosomes indicating liver regeneration. Nucleus appeared rounded with distinct well defined inner and outer membranes and prominent nucleolus (Fig. 18).

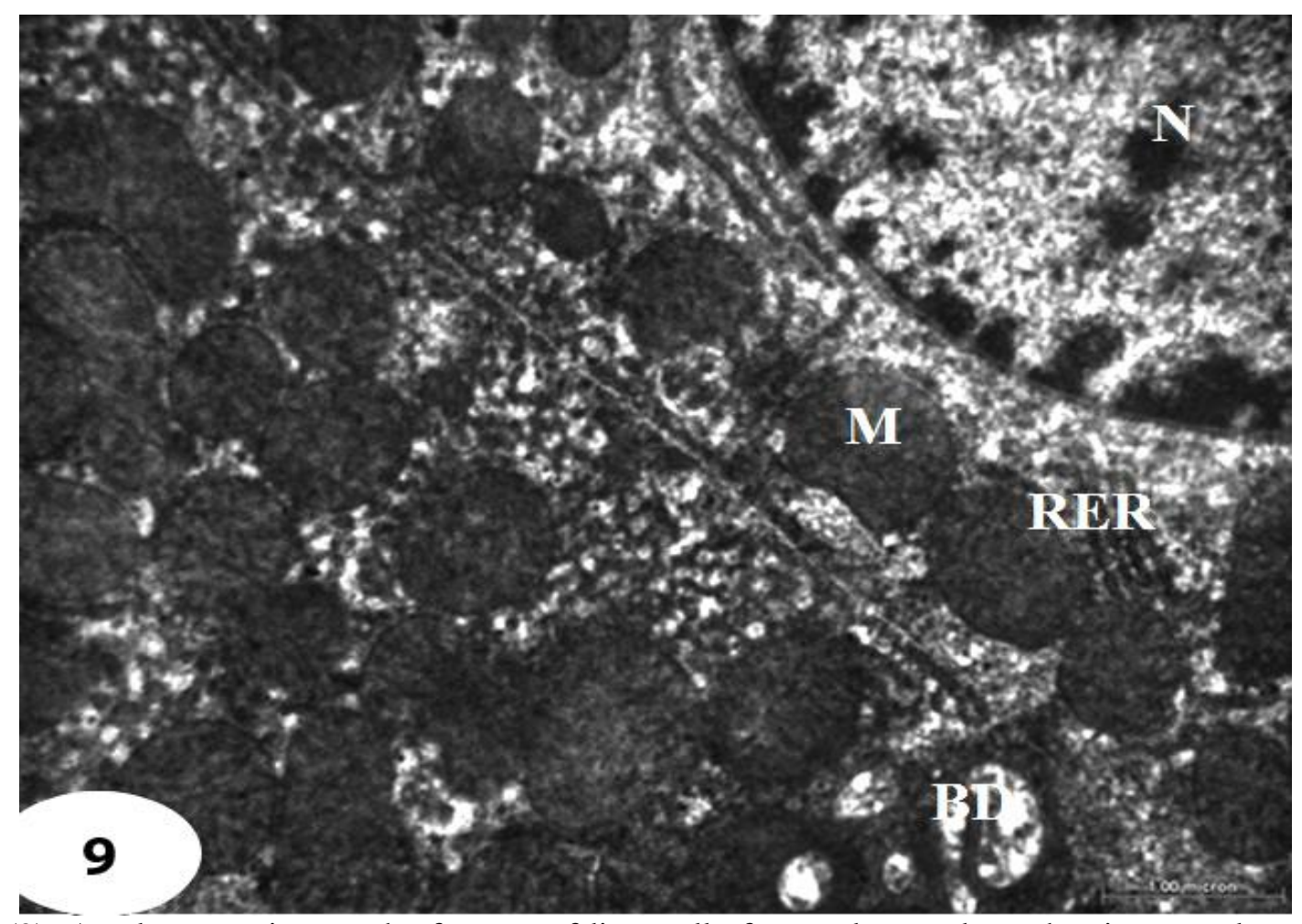

Fig. (9): An electron micrograph of a part of liver cell of control normal rat showing cytoplasm with well defined rounded mitochondria (M), well organized rough endoplasmic reticulum (RER), bile ductule (BD) and distinct nucleus (N) (X 1000). 


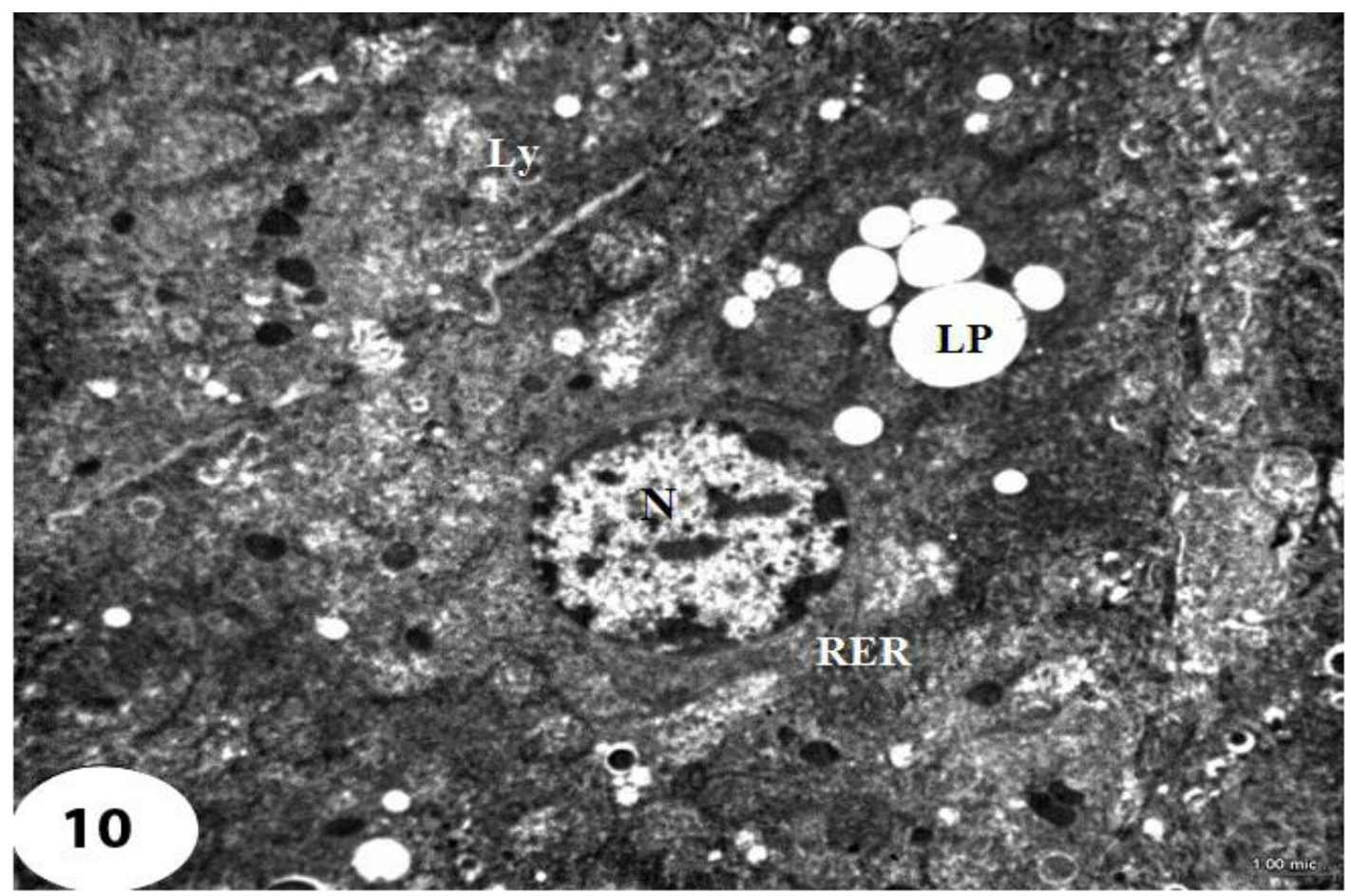

Fig. (10): An electron micrograph of a part of liver cell injected with $\mathrm{CCl}_{4}$ only for 8 weeks showing abnormal cell organoids, mitochondria were malformed and surrounded by fragmented rough endoplasmic reticulum (RER) with increased amount of lipid droplets (LP) and areas of necrosis. The nucleus $(\mathrm{N})$ is rounded and contained disintegrated chromatin (X 4000).

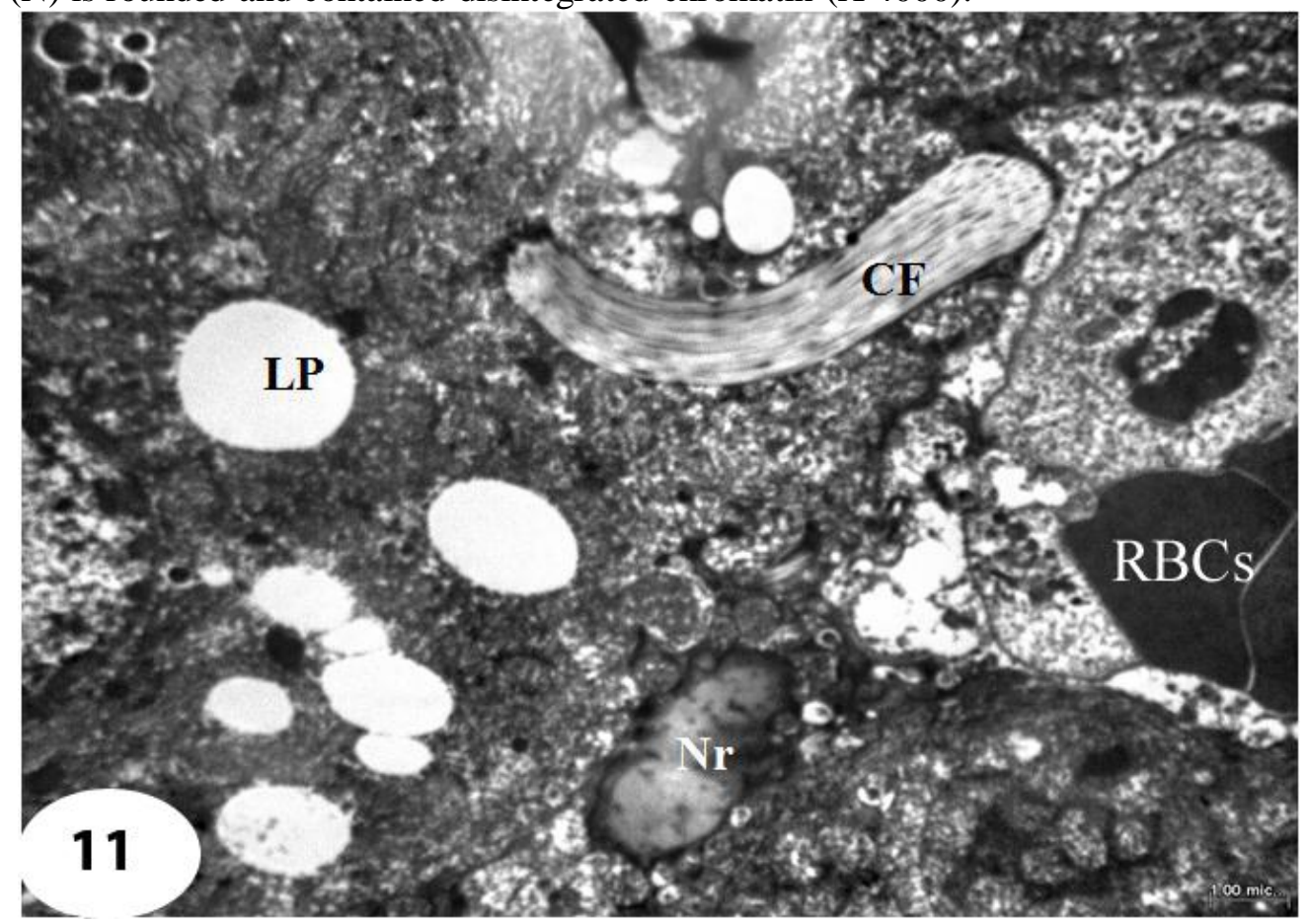

Fig. (11): An electron micrograph of a part of liver cell injected with $\mathrm{CCl}_{4}$ only for 8 weeks showing degenerated cytoplasm with excess collagen fibers (CF), increased amount of lipid droplets (LP) and areas of necrosis $(\mathrm{Nr})$ with red blood cells (RBCs) and white blood cells inside dilated sinusoidal spaces (X 4000). 


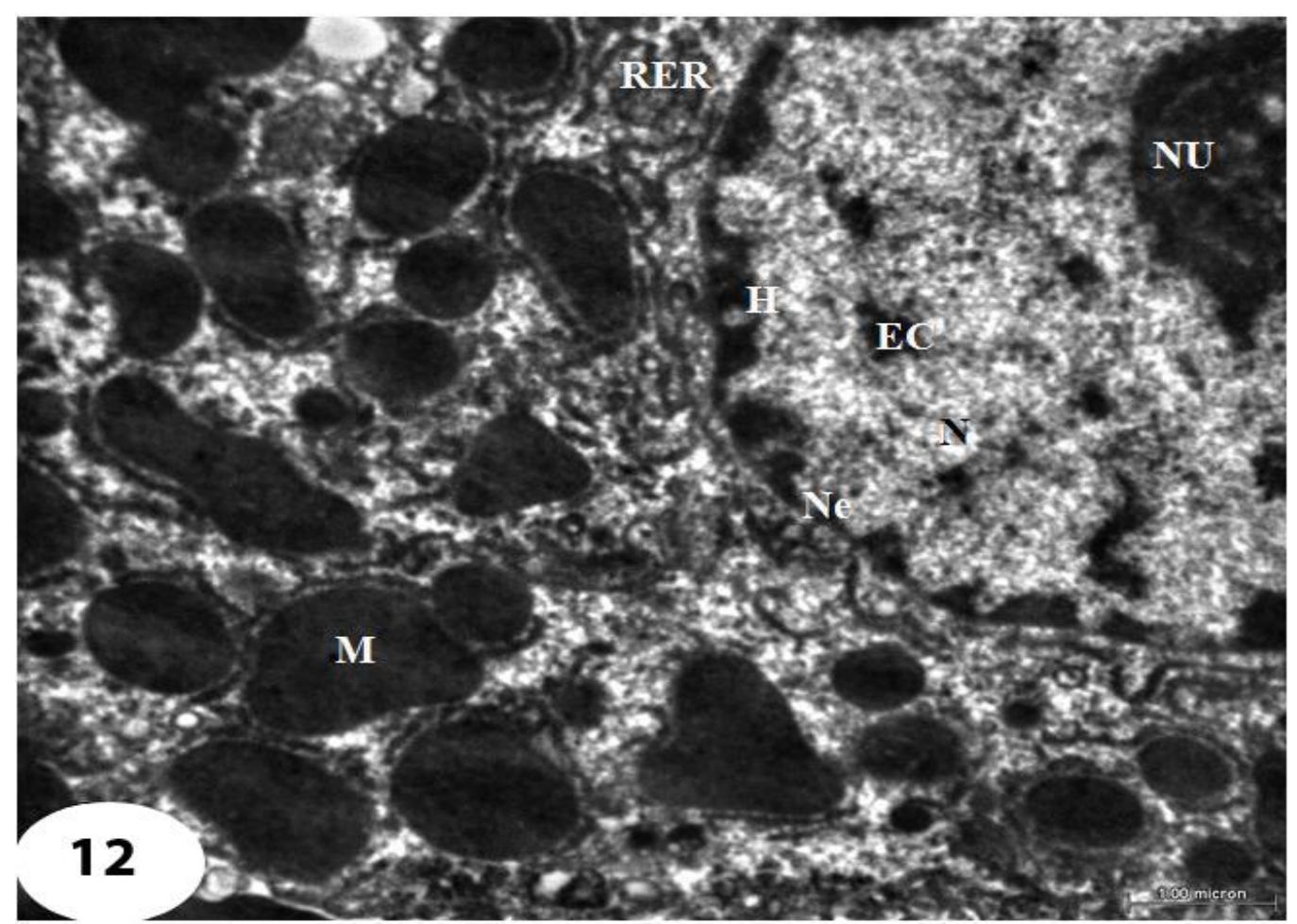

Fig.(12): An electron micrograph of a part of liver cell injected with $\mathrm{CCl}_{4}$ for 8 weeks and treated with bone marrow cells showing homogenous cytoplasm with polymorphic electron dense mitochondria (M), some of which were still swollen and more or less normal rough endoplasmic reticulum (RER). Nucleus (N) appeared normal with distinct outer and inner nuclear envelopes (Ne) containing prominent nucleolus $(\mathrm{NU})$, euchromatin $(\mathrm{EC})$ and heterochromatin $(\mathrm{H})$ attached to the inner nuclear envelope (X 8000).

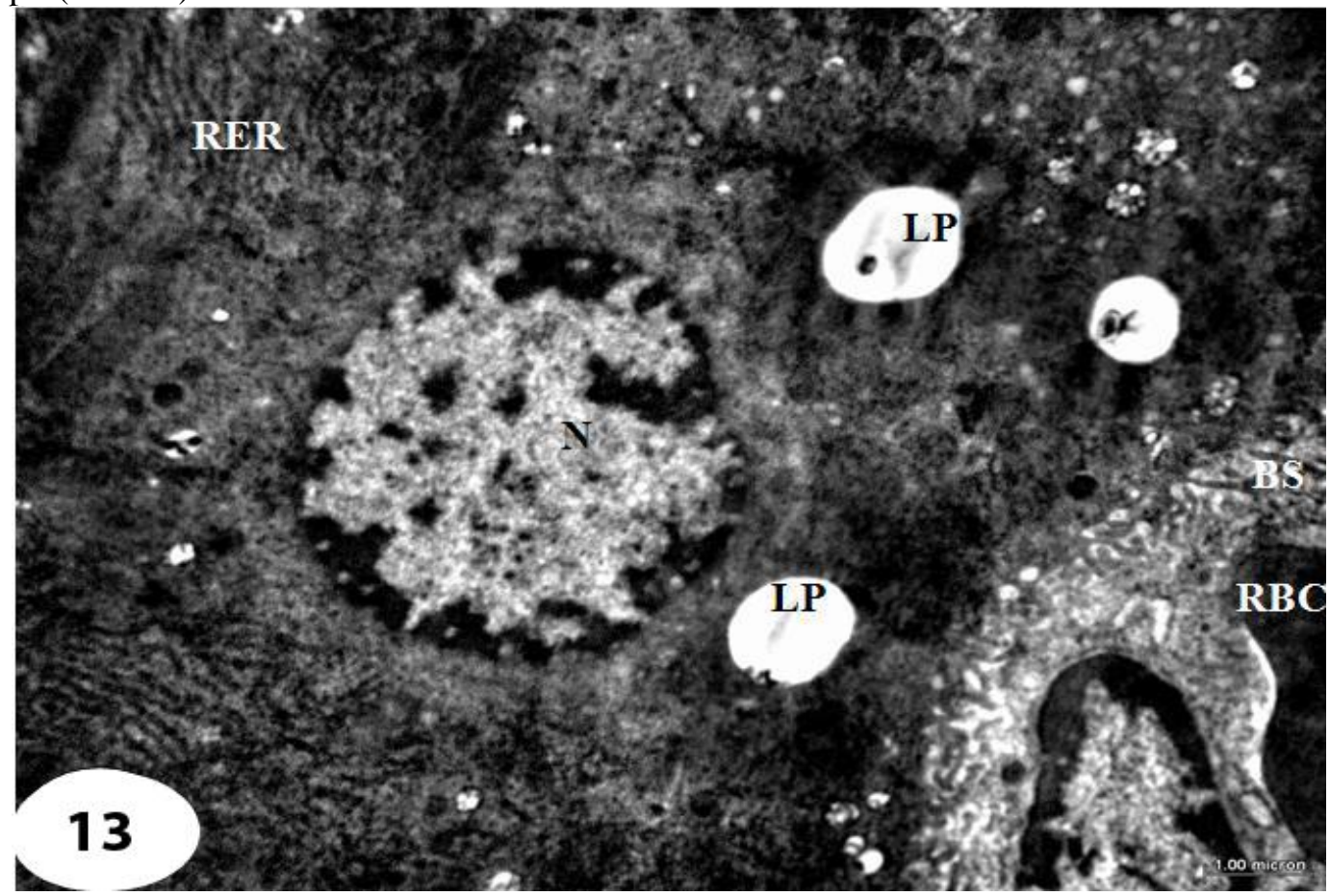

Fig. (13): An electron micrograph of a part of liver cell injected with $\mathrm{CCl}_{4}$ for 8 weeks and treated with bone marrow cells showing increased lipid droplets (LP), dilated blood sinusoid (BS) with red blood cell (RBC) and a leucocyte and nearly normal rough endoplasmic reticulum (RER). Nucleus (N) appeared rounded and more or less healthy (X 6000). 


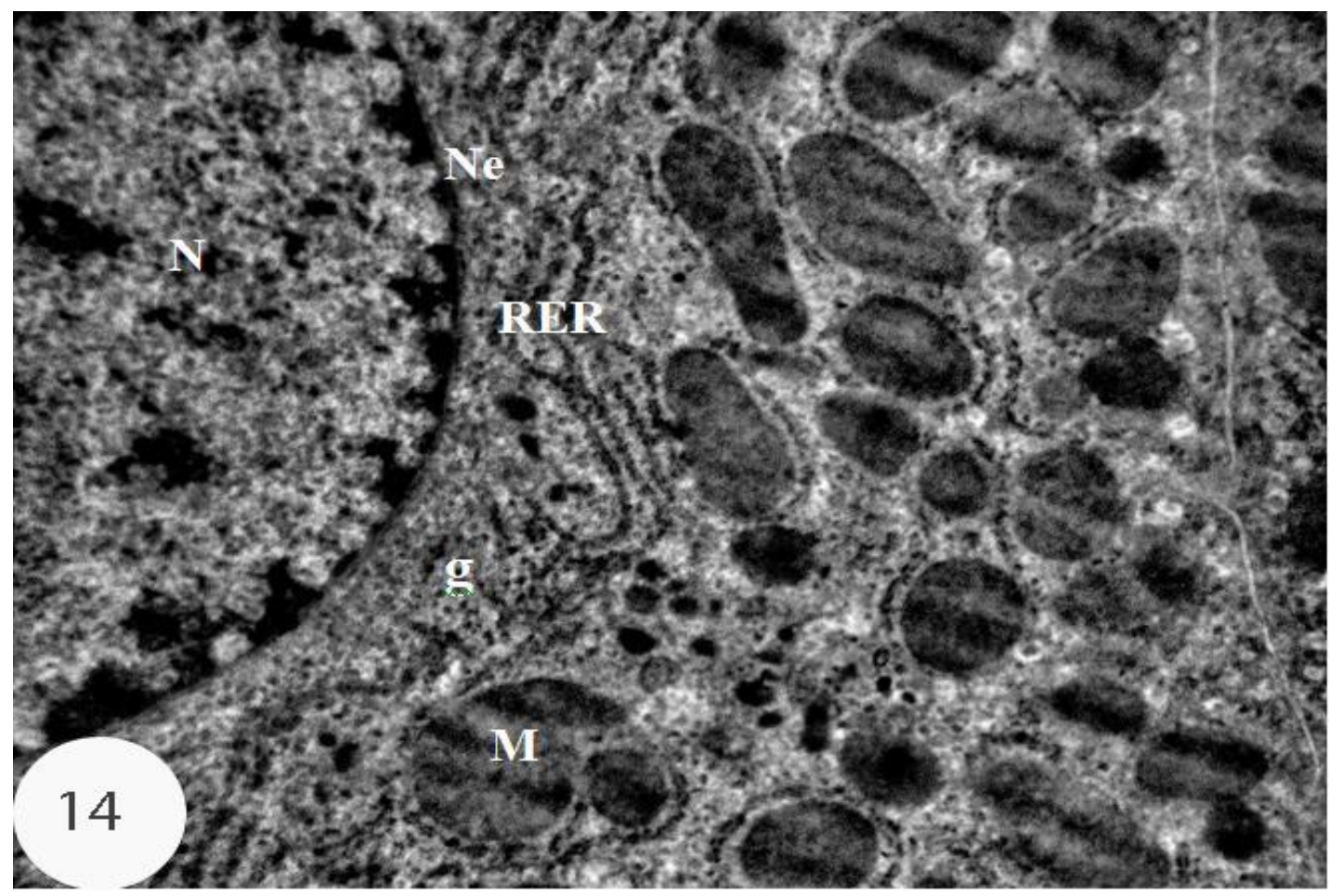

Fig. (14): An electron micrograph of a part of liver cell irradiated with $0.5 \mathrm{~Gy}$ gamma irradiation for 8 weeks showing granulated cytoplasm with rounded and elongated mitochondria (M), smooth and rough endoplasmic reticulums were well organized with normal appearance of glycogen rosette particles $(\mathrm{g})$. Nucleus $(\mathrm{N})$ appeared healthy with its chromatin typically concentrated along the periphery of the nuclear envelope ( $\mathrm{Ne})(\mathrm{X} 10000)$.

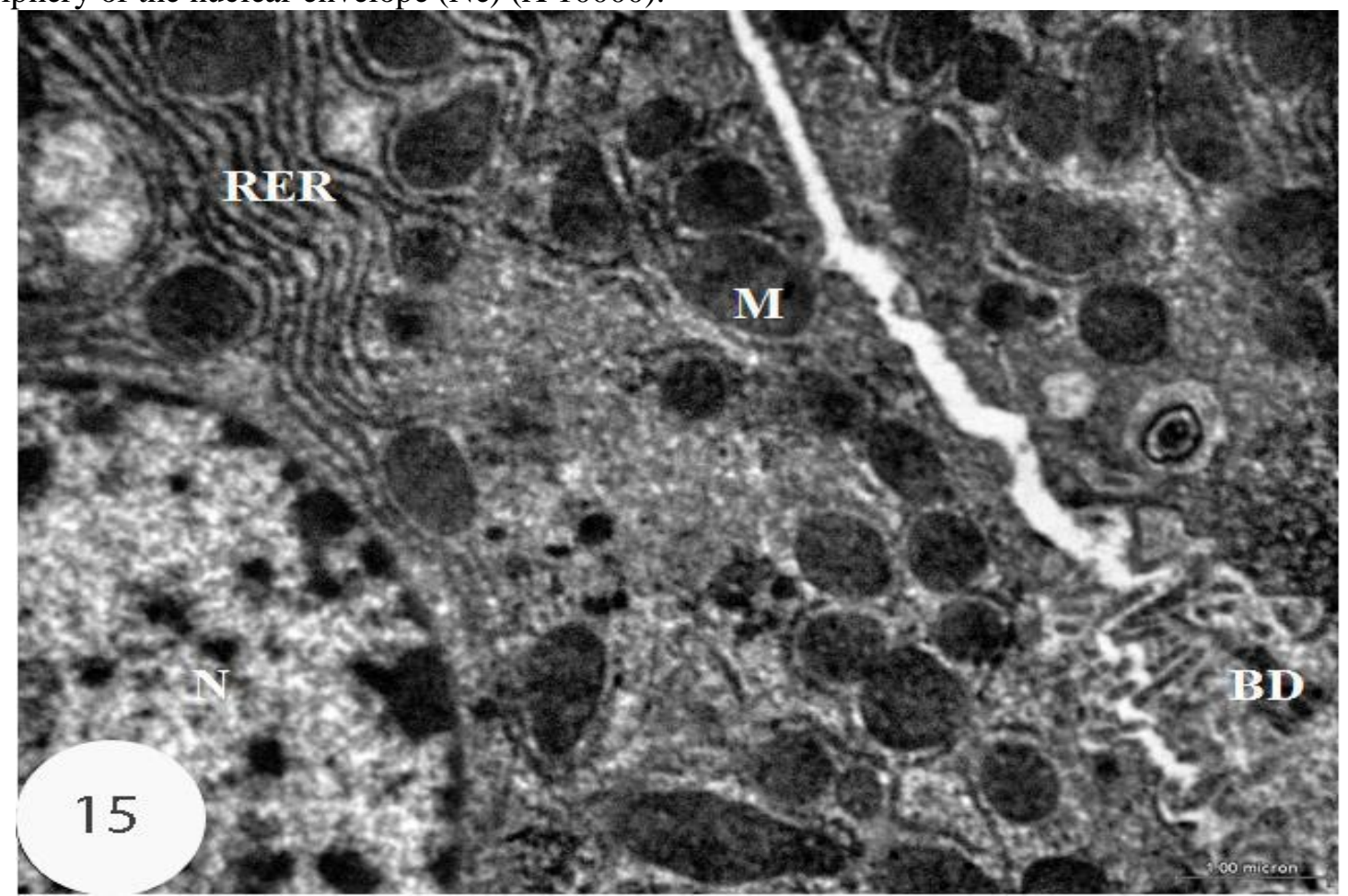

Fig. (15): An electron micrograph of a part of liver cell irradiated with $0.5 \mathrm{~Gy}$ gamma irradiation for 8 weeks and treated with bone marrow cells showing cytoplasm with normal rough endoplasmic reticulum (RER), mitochondria (M) which appeared more electron dense, glycogen particles and microvilli (BD) in between two hepatocytes. Normal healthy nucleus (N) was also noted (X 8000). 


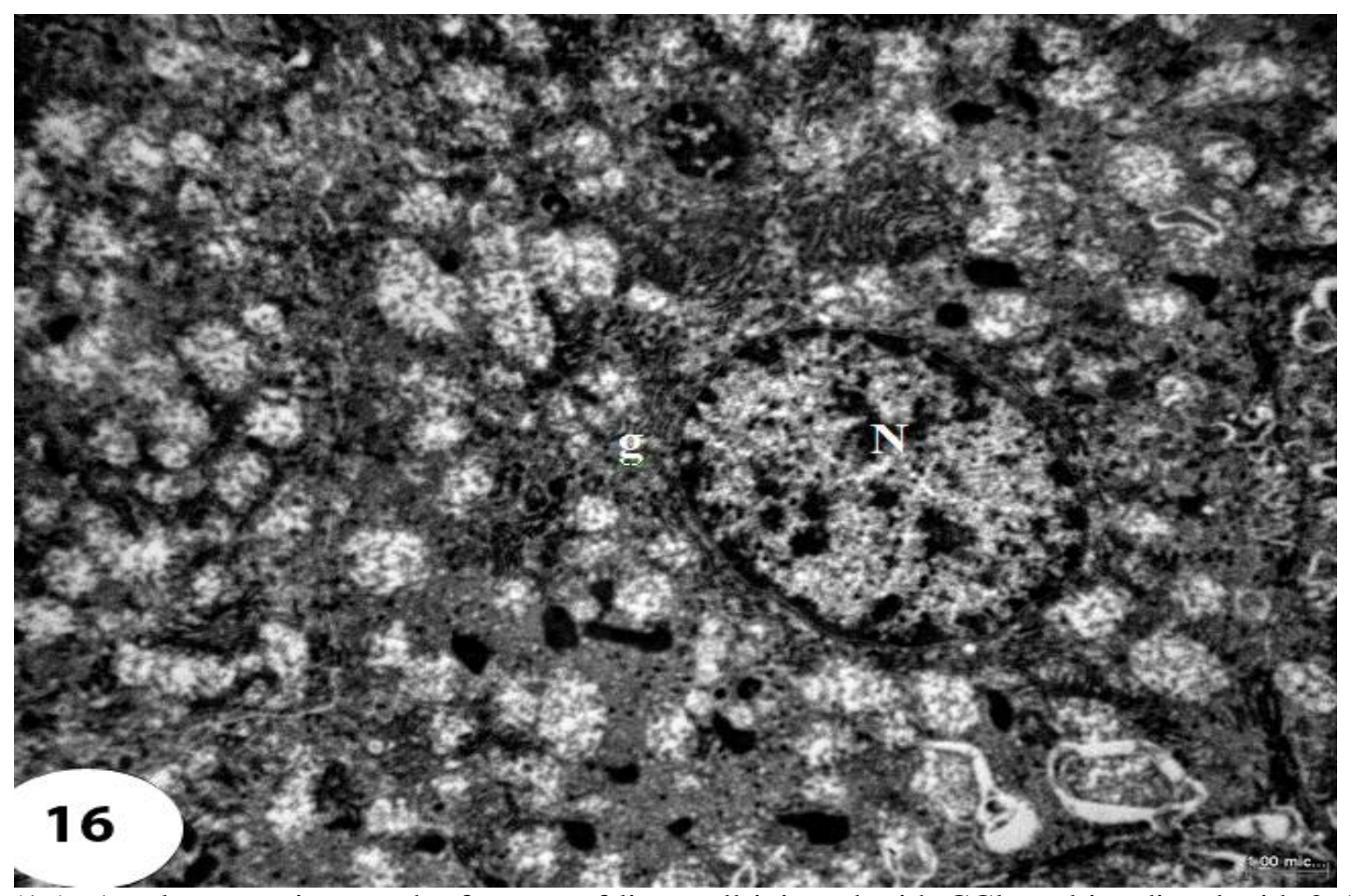

Fig. (16): An electron micrograph of a part of liver cell injected with $\mathrm{CCl}_{4}$ and irradiated with $0.5 \mathrm{~Gy}$ of gamma radiation for 8 weeks showing slight improvement of the hepatocytes where cytoplasm appeared homogenous with electron dense deposited materials and disappearance of rough endoplasmic reticulum. Glycogen rosettes also appeared scattered throughout the cytoplasm and nucleus $(\mathrm{N})$ appeared semi rounded and healthy (X 4000).

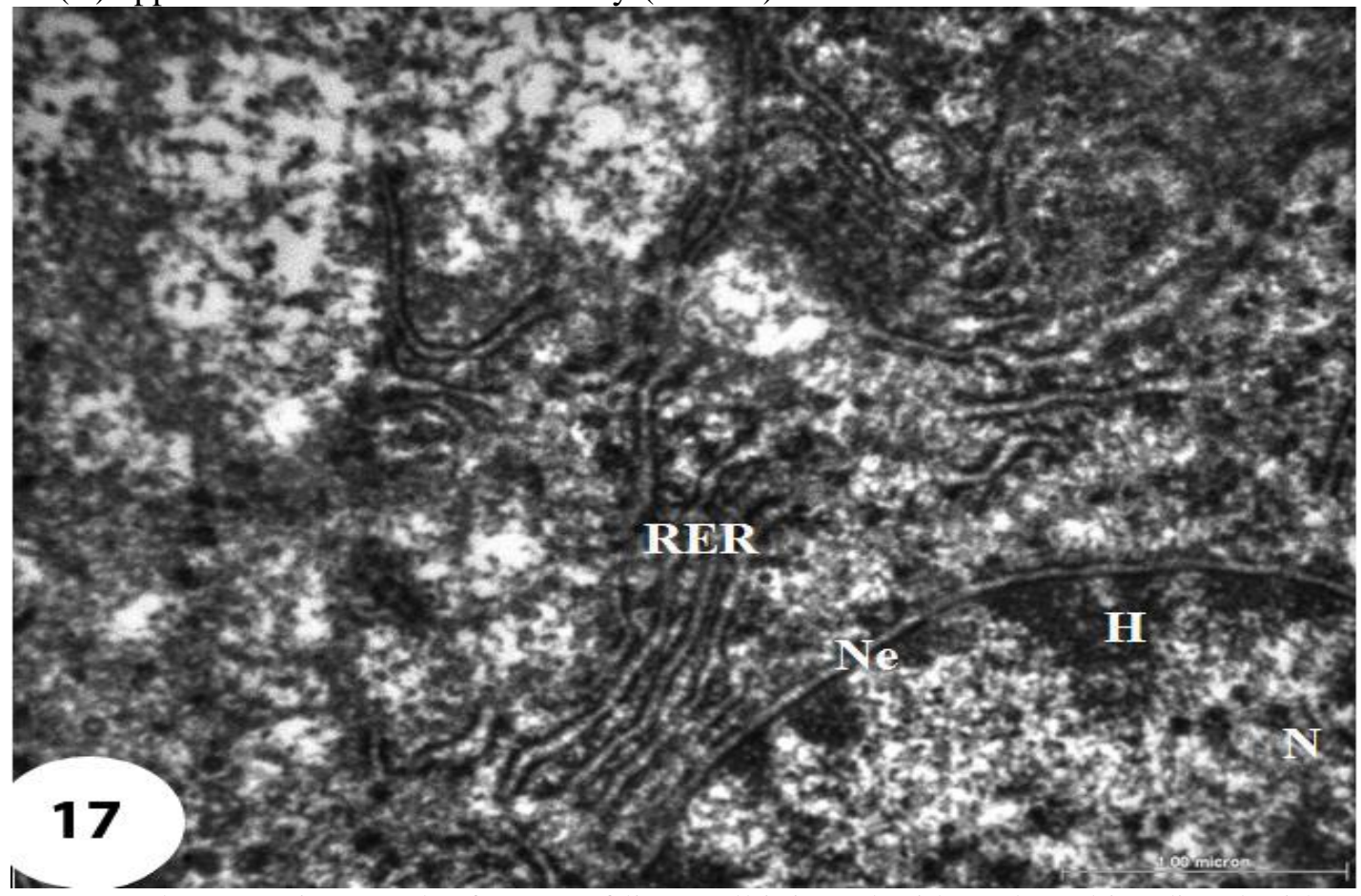

Fig. (17): An electron micrograph of a part of liver cell injected with $\mathrm{CCl}_{4}$ and irradiated with $0.5 \mathrm{~Gy}$ of gamma radiation for 8 weeks showing incomplete recovery where cytoplasm appeared with electron dense deposited materials and nearly normal rough endoplasmic reticulum (RER). A part of the nucleus $(\mathrm{N})$ with distinct outer and inner nuclear envelopes $(\mathrm{Ne})$ and marginal heterochromatin
(H)
was
also
seen
(X
15000). 


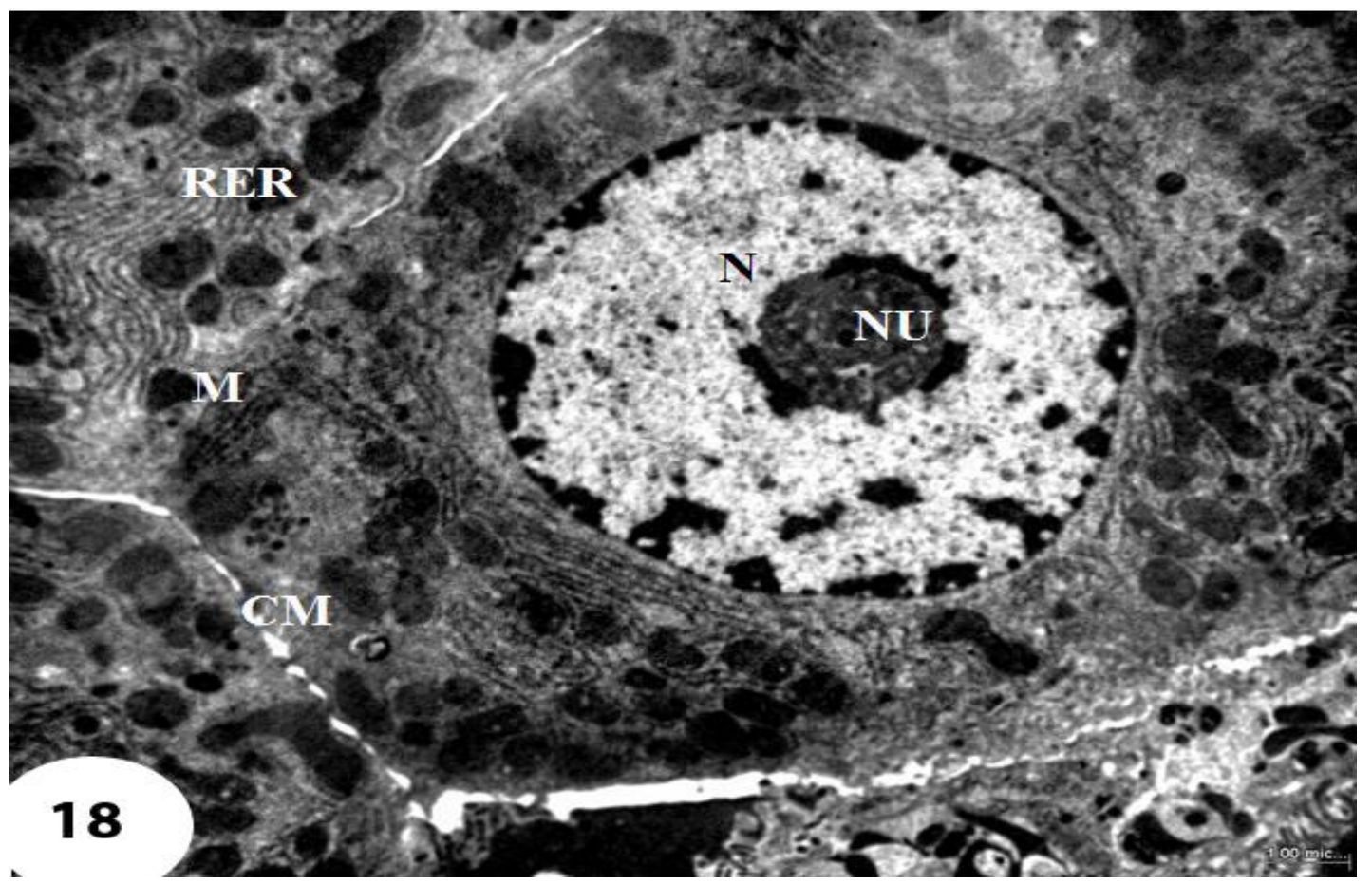

Fig. (18): An electron micrograph of a part of liver cell injected with $\mathrm{CCl}_{4}$, irradiated with $0.5 \mathrm{~Gy}$ of gamma radiation for 8 weeks and treated with bone marrow cells showing well defined cell membrane $(\mathrm{CM})$, the cytoplasm appeared homogenous contained nearly normal mitochondria $(\mathrm{M})$ with different shapes, well organized rough endoplasmic reticulum (RER). The nucleus $(\mathrm{N})$ appeared more or less normal with well defined inner and outer membranes and prominent nucleolus (NU) (X 4000). 



\section{Discussion}

The liver is a vital organ that playing a major role in metabolism and has a number of functions in the body, including glycogen storage, decomposition of red blood cells, plasma protein synthesis and hormone production.

The current experiment showed that eight weeks after carbon tetrachloride administration to rats the liver appeared with marked changes where some hepatocytes showed complete destruction with pyknosis of their nuclei and many inclusions inside the cytoplasm indicating last stage of cell death. Other hepatocytes showed depletion of the cellular membranes, degenerated and granulated cytoplasm, severe fatty changes persistent with scattered inflammatory foci and necrosis. These observations were reported earlier by George et al. (2001) who found severe centrilobular congestion and hemorrhagic necrosis, centrilobular necrosis and intense neutrophilic infiltration, with focal fatty changes and fibrosis. Moreover, hepatocytes swelling, cytoplasmic degeneration and variation in liver cell sizes, with collagen fiber deposition were also noted indicating the drastic effects of carbon tetrachloride. Such observations go in agreement with those reported earlier (Aghel et al., 2007; Lopez-Reyez et al., 2008; Xu et al., 2011).

The mechanism of these liver changes could be attributed to the fact that carbon tetrachloride is bio-transformed by the cytochrome $\mathrm{P}_{450}$ system in the endoplasmic reticulum to produce trichloromethyl free radical $\left({ }^{*} \mathrm{CCl}_{3}\right)$. This free radical then combined with cellular lipids and proteins in the presence of oxygen to form a trichloromethyl peroxyl radical, which may attack lipids on the membrane of endoplasmic reticulum faster than trichloromethyl free radical. Thus, trichloromethylperoxyl free radical elicit lipid peroxidation, the destruction of $\mathrm{Ca}^{2+}$ homeostasis, and finally, results in cell death (Mohona Rao et al., 2006) where $\mathrm{CCl}_{4}$ interferes with calcium homeostasis in two basic ways. It promotes influx of calcium ions into the cytoplasm (by physically disrupting membrane integrity via lipid peroxidation and by opening certain membrane calcium transport channels). It also inhibits active transport of calcium ions out of the cytoplasm (Manibusan et al., 2007). Calcium also could contribute to cell death by the over stimulation of calcium-responsive cellular enzymes that initiate a cascade of events, resulting in irreversible cell injury.

The present experiment showed marked improvement of the liver in $\mathrm{CCl}_{4}$ injected rats following intravenous injection of bone marrow cells (BMC), where most of the hepatocytes nuclei restored their normal appearance, while others showed that the process of degeneration proceeded to necrotic areas indicating the therapeutic effect of bone marrow cells transplantation. Such observations comes in coincidence with the results of Sakaida et al. (2005) and Sakaida (2006) who indicated that bone marrow cell transplantation into mice with liver cirrhosis improved liver function and liver fibrosis, resulting in an improved survival rate. Moreover, bone marrow cells infused into the rats showed improvement of liver fibrosis in rats (Cao et al., 2007).

Low-dose radiation has been shown to enhance biological responses for immune systems, enzymatic repair, physiological functions, and the removal of cellular damage, including prevention and removal of cancers and other diseases. Research on low-level radiation has also shown it to have no adverse effects.

The present experiment showed an improvement of rat liver in the group that injected with $\mathrm{CCl}_{4}$ and subjected to low doses (0.5 Gy) gamma radiation for eight weeks where most of the hepatocytes appeared healthy and their nuclei were in mitotic stage with condensed granulated cytoplasm. Examined sections showed nearly normal appearance of the collagen fibers deposition but mitochondria were still affected and has ruptured cristae. The improvement of liver cells in this experiment after low dose radiation and carbon tetrachloride administration could be due to the beneficial health effects following low doses of ionizing radiation (Calabrese and Baldwin, 2000). Low dose radiation has a stimulatory or hormetic effect where high doses of radiation are known to be harmful to living organisms but also low doses of ionizing radiation may in 
fact beneficial to the health of an organism. The entire mechanisms of radiation hormesis still unknown but some theories may explain this process where Mortazavi et al. (2009) reported that low doses of ionizing radiation induce the production of special proteins, that are involved in DNA repair processes, it could also cause a temporary inhibition of DNA synthesis and this temporary inhibition of DNA synthesis would provide a longer time for irradiated cells to recover. This inhibition also may induce the production of free radical scavengers. Moreover, low doses of ionizing radiation may stimulate the functions of the immune system.

Low doses of gamma rays have been demonstrated to induce defense such as detoxification of reactive oxygen species, induce high-fidelity repair of DNA damage, protect from chromosomal damage caused by subsequent high radiation dose and protect from spontaneous mutations occurrence (Rothkamm and Löbrich, 2003; Feinendegen et al., 2004; Hooker et al., 2004) and activate the immune response (Liu, 2004). It also stimulates various biological functions: anti-oxidative capacity, DNA repair capability and apoptosis, enzymatic repair and immunological and apoptotic removal of DNA damage (Pollycove and Feinendegen 2000; Sakai, 2000).

So, the mechanism of liver improvement, in this experiment, after low dose radiation and carbon tetrachloride administration appear to be attributed to two principal types of adaptive protection, one is to prevent and repair DNA damage and in doing so to keep cells alive and functioning properly. The other is to remove damaged cells from tissue by inducing apoptosis, terminal differentiation and immune responses and thus to reduce genomic instability in the tissue system and eliminate mutated cells which comes in coincidence with those reported earlier by Liu (2004) and Feinendegen (2005). Moreover, $\gamma$-irradiation was reported previously to decrease carbon tetrachloride-induced lipid peroxidation and liver cirrhosis (Grudziński $\boldsymbol{e t}$ al., 2000) and modulate the antioxidant defense system in rat liver.

The current experiment showed marked improvement of the liver in both $\mathrm{CCl}_{4}$ and 0.5 Gy gamma irradiated rats following an intravenous injection of bone marrow cells where liver sections examination revealed nearly normal appearance of the hepatocytes and blood sinusoids. Marked reduction in the collagen fibers deposition was also noted indicating the therapeutic effect of bone marrow transplantation where bone marrow cells have been demonstrated to differentiate into hepatocytes after transplantation into the liver (Lee et al., 2004; Wang et al., 2004). So, rat liver improvement in all the examined groups of this experiment after bone marrow injection could be attributed to one of or all the following mechanisms that have been postulated to explain the bone marrow cells role in liver repair:

1- Transdifferentiation:

It takes place when an adult cell is transformed into a different type of cell and may occur in this experiment during bone marrow cells transplantation to rats which comes in full agreement with those reported by Jang $\boldsymbol{e t} \boldsymbol{a l}$. (2004) who reported that purified hematopoietic stem cells differentiate into albumin secreting hepatocytes when cocultured with carbon tetrachloride treated liver tissue.

2- Cell fusion:

Where, bone marrow cells could form hepatocytes via cell fusion (Lorenzini and Andreone, 2007).

3- The bystander effect:

Where, the transplanted bone marrow cells stimulate the resident hepatocytes proliferation. Thus, if the liver is injured, the stimulus for endogenous liver cells might occur through factors secreted by bone marrow derived cells (Allen et al., 2005).

\section{References}

Allen K J, Buck N E, Williamson R (2005): Stem cells for the treatment of liver disease. Transpl. Immunol., 15: 99-112.

Aghel N, Rashidi I and Mombeini A (2007): Hepatoprotective activity of Capparis spinosa root bark against $\mathrm{CCl}_{4}$ induced hepatic damage in mice. Iranian J. Pharmaceut. Res., 6 (4): 285-290.

Calabrese E J and Baldwin L A (2000): Radiation hormesis: origins, history, scientific foundations. Human \& Exp. Toxicol., 19 (1 ):2-97.

Cao B Q, Lin J Z, Zhong Y S, Huang S B, Lin $N$, Tang $Z \mathbf{F}$, Chen $R$, Xiang $P$ and $X u R ~ Y$ (2007): Contribution of mononuclear bone marrow cells to carbon tetrachloride-induced liver fibrosis 
in rats. World J. Gastroenterol., 13 (12): 18511856.

Cuttler J M (2001): The Significant Health Benefits of Nuclear Radiation. 21 $1^{\text {st }}$ Century Science \& Technology, 14 (3): 1-10.

Dai L J, Li H Y, Guan L X, Rit chie G, and Zhou J X (2009): The therapeutic potential of bone marrow-derived mesenchymal stem cells on hepatic cirrhosis. Stem Cell Research, 2: 16-25.

Feinendegen L E (2005): Evidence for beneficial low level radiation effects and radiation hormesis. The British J. Radiol., 78: 3-7.

Feinendegen L E, Pollycove M and Sondhaus C A (2004): Responses to low doses of ionizing radiation in biological systems. Nonlin. Biol. Toxicol. Med., 2 (3): 143-171.

Kwon D S, Gao X, Liu Y B, Dulchavsky D S, Danyluk A L, Bansal M, Chopp M, McIntosh K, Arbab A S, Dulchavsky S A and Gautam S C (2008): Treatment with bone marrow-derived stromal cells accelerates wound healing in diabetic rats. Int. Wound J., 5 (3): 453-463.

George J, Rao K R, Stern R and Chandrakasan G (2001): Dimethylnitrosamine-induced liver injury in rats: the early deposition of collagen. Toxicology, 156 (2-3): 129-138.

Gines P, Cardenas A, Arroyo V, and Rodes J (2004): Management of cirrhosis and ascites. N. Engl. J. Med., 350: 1646 - 1654.

Grudziński I P, Frankiewicz-Jozko A, Gajewska J, Szczypka $M$ and Szymanski A (2000): Effects of whole-body $\gamma$-irradiation on lipid peroxidation and anti-oxidant enzymes in the liver of N-nitrosodiethylamine-treated mice. Polish J. Environ. Studies, 9 (5): 385-390.

Hooker A M, Bhat M, Day T K, Lane J M, Swinburne S J, Morley A A and Sykes P J (2004): The linear no threshold model does not hold for low-dose ionizing radiation. Radiat. Res., 162: 447- 452.

Jang Y Y, Collector M I, Baylin S B, Diehl A M and Sharkis S J (2004): Hematopoietic stem cells convert into liver cells within days without fusion. Nat. Cell Biol., 6: 532-539.

Kamalakkannan N, Rukkumani R, Varma $P$ $S$, Viswanathan $P$, Rajasekharan $K \mathbf{N}$ and Menon V P (2005): Comparative effects of curcumin and an analogue of curcumin in carbon tetrachloride-induced hepatotoxicity. Basic and Clinical Pharmacology and Toxicology, 97 (1): 1522.

Lee K D, Kuo T K, Whang-Peng J, Chung Y F, Lin C T, Chou S H, Chen J R, Chen Y P, Lee $O$ K (2004): In vitro hepatic differentiation of human mesenchymal stem cells. Hepatology, 40: $1275-1284$.

Liu $S \mathbf{Z}$ (2003): On radiation hormesis expressed in the immune system. Crit. Rev. Toxicol., 33: 431441.
Liu S Z (2004): Radiation-induced change in lymphocyte proliferation and its neuroendocrine regulation: Dose-response relationship and pathophysiological implications. Nonlin. Biol. Toxicol. Med., 2 (3): 233-244.

Lopez-Reyes A G, Arroyo-Curras N, Cano B G, Lara-Diaz V G, Guajardo-Salinas G E, Islas J F, Morales-Oyorvide V, Morales-Garza L A, Galvez-Gastelum F J, Grijalva G and MorenoCuevas J E (2008): Black been extract ameliorates liver fibrosis in rats with $\mathrm{CCl}_{4}$-induced injury. Ann. Hepatol., 7 (2): 130-135.

Lorenzini $S$ and Andreone $P$ (2007): Regenerative medicine and liver injury: what role for bone marrow derived stem cells?. Curr. Stem Cell Res. \& Ther., 2: 83-88.

Manibusan M K, Odin M and Eastmond D A (2007): Postulated carbon tetrachloride mode of action: A Review. J. Environ. Sci. and Health, 25: 185-209.

Mohona Rao G M, Rao C V, Pushpangadan P and Shirwaikar A (2006): Hepatoprotective effects of rubiadin, a major constituent of Rubia cordifolia. J. Ethnopharmacol., 103: 484-490.

Mortazavi S M J, Rahmani M R, Rahnama A, Saeed-Pour A, Nouri E, Hosseini $\mathbf{N}$ and Aghaiee M M (2009): The stimulatory effects of topical application of radioactive lantern mantle powder on wound healing. Dose Resp., 7 (2): 149159.

Pollycove $M$ and Feinendegen L E (2000): Cellular and organism dose-response: bio-positive (health benefit) effects, in Proceedings of International Symposium on Health Benefits of Low-Dose Radiation - The Science and Medical Applications, Washington, D.C.,

Rajeswary H, Vasuki R, Samudram $P$ and Geetha A (2011): Hepatoprotective action of ethanolic extracts of Melia azedarach Linn. and Piper longum Linn. and their combination on $\mathrm{CCl}_{4}$ induced hepatotoxicity in rats. Ind. J. Exp. Biol., 49: 276-281.

Rothkamm K and Löbrich M (2003): Evidence for a lack of DNA double-strand break repair in human cells exposed to very low x-ray doses. PNAS, 100 (9): 5057-5062.

Sakai K (2000): Biological Effects of Low Dose Radiation, Excerpta Medica International Congress Series 1211. Elsevier: p. 53.

Sakaida I (2006): Cell therapy with bone marrow cell for liver cirrhosis. J. Electrophoresis, 50: 7-12.

Sakaida I, Terai S, Yamamoto N, Aoyama K, Ishikawa T, Nishina $H$ and Okita $K$ (2004): Transplantation of bone marrow cells reduces $\mathrm{CCl}_{4}$-induced liver fibrosis in mice. Hepatology, 40 (6): 1304- 131.

Sakaida I, Terai S, Nishina $H$ and Okita K (2005): Development of cell therapy using 
autologous bone marrow cells for liver cirrhosis. Med. Mol. Morphol., 38: 197-202.

Skepper J N and Powell J M (2006): Immunohistochemistry: Methods Express (ed. Renshaw), from the Methods Express series. Scion Publishing Ltd., Oxfordshire, UK.

Smyth R, Munday M R, York M J, Clarke C J, Dare T and Turton J A (2007): Comprehensive characterization of serum clinical chemistry parameters and the identification of urinary superoxide dismutase in a carbon tetrachlorideinduced model of hepatic fibrosis in the female Hanover Wistar rat. Int. J. Exp. Pathol., 88: 361376.

Sun C K, Chen C H, Kao Y H, Yuen C M, Sheu J J, Lee F Y, Chen Y T, Kung $C \mathrm{~T}$ and Yip H K (2010): Bone marrow cells reduce fibrogenesis and enhance regeneration in fibrotic rat liver. J. Surgical Res., 1-19.
34. Terai S, Ishikawa T, Omori K, Aoyama K, Marumoto Y, Urata Y, Yokoyama Y, Uchida K, Yamasaki T, Fujii Y, Okita $K$ and Sakaida I (2006): Improved liver function in patients with liver cirrhosis after autologous bone marrow cell infusion therapy. Stem Cell, 24: 22922298.

Wang $P$ P, Wang $J$ H, Yan $Z$ P, Hu M Y, Lau G K, Fan S. T and Luk J M (2004): Expression of hepatocyte like phenotypes in bone marrow stromal cells after HGF induction. Biochem. Biophys. Res. Commun., 320: 712- 716.

Wernke M J and Schell J D (2004): Solvents and malignancy, Clinics in Occupational and Environmental Medicine, 4 (3): 513-527.

Xu L, Gao J, Wang Y, Yu W, Zhao X, Yang $\mathbf{X}$, Zhong $\mathbf{Z}$ and Qian $\mathbf{Z}$ (2011): Myrica rubra extracts protect the liver from $\mathrm{CCl}_{4}$-induced damage. Evidence-Based Complementary and Alternative Medicine, 2011:1-8. 


\title{
التأثير العلاجي لزرع خلايا نخاع العظام مع / أو التعرض لجرعابه منخفضه من أثُعه جاما على الاصابات الكبديه الناجمه عن عن رابع التعرم كلوريد الكريون.
}

\author{
محمد السيد محمد زويل* هناء فتحى محمود واعر** نعمان عبد اللطيف الطحاوى ** ايمان حامد شاكرخاطر* عمرو

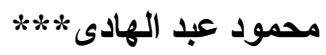

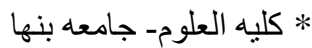

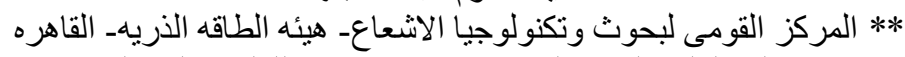

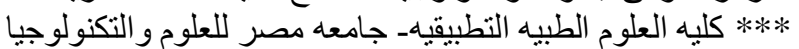

يعتبر الكبد أكثر أعضاء الجسم اصابه بالتسمم بالمو اد الكيميائيه مثل رابع كلوريد الكربون ويهذف هذا البحث الى الى إئ

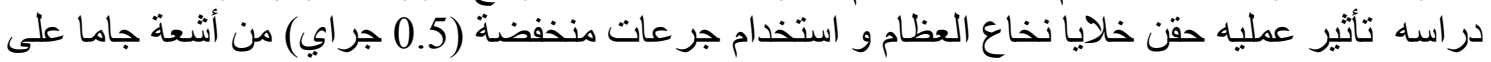

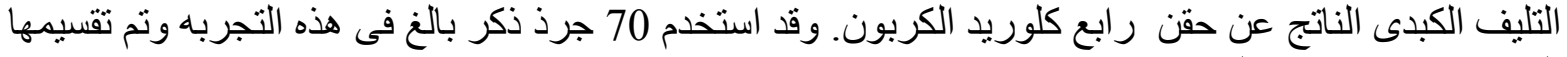
الى 7 مجمو عات كما يلى الني:

1 1 1. مجمو عة جرذان ضنابطه.

2. 3. مجمو عه جرذان تم حقنها بر ابع كلوريد الكربون.

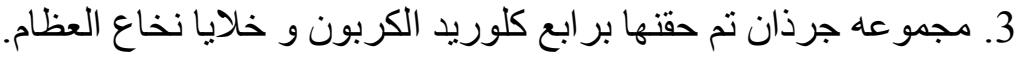

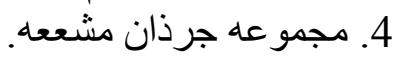

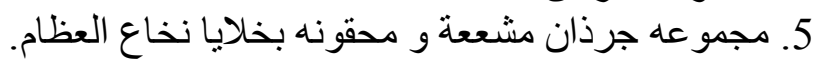

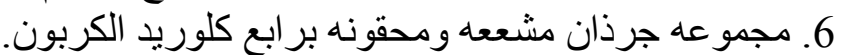

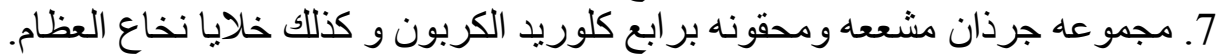

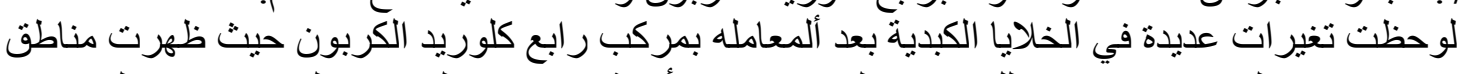

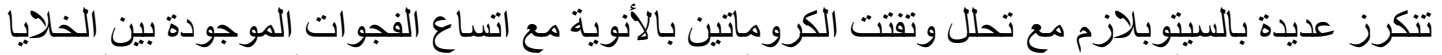

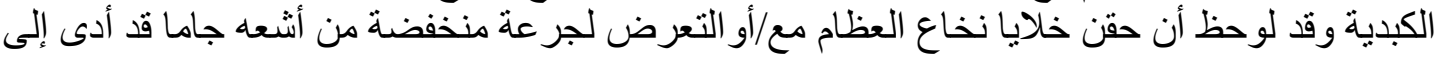

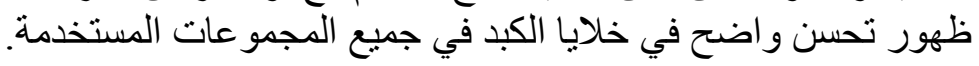

